\title{
PRELIMINARY SUCCESS ON HORMONE INDUCED BREEDING OF STRIPED MULLET (MUGIL CEPHALUS L.) IN BANGLADESH
}

\author{
Ehsanul Karim*, Jakia Hasan and M. Enamul Hoq \\ Marine Fisheries and Technology Station, Bangladesh Fisheries Research Institute \\ Cox's Bazar 4700, Bangladesh
}

\begin{abstract}
Induced breeding trial of two years old striped mullet (Mugil cephalus L.) was conducted during winter season in a commercial fish hatchery at Cox's Bazar, Bangladesh. Adult or subadults of $M$. cephalus were collected from the wild and reared in the saline ponds from August to December 2014. The broods were injected using carp PG, HCG and LRH- $\mathrm{A}_{2}$ after 48 hrs of acclimatization in the hatchery tanks. The effective doses of carp PG $30 \mathrm{mg} / \mathrm{kg}$ body weight, LRH-A $2150 \mu g$ with a combination of $0.3 \mathrm{ml}$ Domperidone and 0.5 $\mathrm{ml}$ Calcium injection, and HCG dose of 30,000 IU in case of female and 5,000 IU in case of male were found to spawning success. The GSI value ranged between 7.92-12.38 and egg diameter of matured fish ranged between $563-594 \mu \mathrm{m}$ and that of fertilized egg between $650-680 \mu \mathrm{m}$ with fecundity calculated as 780 to $900 \mathrm{nos} / \mathrm{g}$. The fish started spawning between 44-48 hrs and cell division was observed after the first hour of spawning, however, mass mortality occurred after $6 \mathrm{hrs}$ of spawning.
\end{abstract}

Key words: Mugil cephalus, breeding, spawning

\section{INTRODUCTION}

Striped mullet (Mugil cephalus L.) is traditionally cultured along with tiger shrimp in coastal shrimp farms of Bangladesh coast. This is a euryhaline and eurythermal species that contributes to coastal fisheries not only in Bangladesh but also in China (Chang et al. 2004), Egypt (Saleh 2008), India (Curian 1975 and Barman et al. 2005), Sri Lanka (De Silva and Silva 1979), Taiwan (Chang et al. 2000) etc. Although there is no deliberate practice to stock the shrimp farms with mullet fry but the species is cultured in the shrimp ghers in the coastal region of Bangladesh where they enter with the tidal water during water exchanges. They grow well with the shrimps but they fed on the juvenile shrimps and resulted lower shrimp yield. However, the species is considered as demandable fish for its taste and price.

Although, the mullet fry and juveniles are available in the wild, aquaculture sector cannot thrive depending on the wild seed supply. Study on reproductive biology of $M$. cephalus in Bangladesh attempted (Das et al. 2008), although induced breeding techniques of this species not yet developed. Studies on

\footnotetext{
* Corresponding author: hoq_me@yahoo.com
}

(C) 2015 Zoological Society of Bangladesh DOI: 10.3329/bjz.v43i2.27398 
induced breeding of mullets in Indian sub-continent by pituitary injection were initiated during 1961 in India and success was achieved by hypophysation in breeding of $M$. cephalus by CIFRI (1961) followed by induced spawning using carp pituitary gland and leutenizing hormone (Yashouv and Sampsonov 1970). Kuo et al. (1974) also established spawning procedures for M. cephelus in Israel. Thus to ensure adequate supply of mullet seed for coastal aquaculture, knowledge about its artificial breeding technology is prerequisite and hence the present induced breeding experiment was carried out in a fish hatchery at Cox's Bazar.

\section{MATERIAL AND METHODS}

Study area: The experiment was conducted from August 2014 to February 2015 in Niribili Fish Farm, Rejukhal, Cox's Bazar. Two (50-60 decimal sized) brood rearing ponds- equal in depth and configuration including water inlet and outlet system were used. The water depth was maintained at a maximum of $1.4 \mathrm{~m}$.

Brood development: Adult or sub-adults of $M$. cephalus were collected from the wild and stocked in saline ponds (15-20 ppt) of Niribili Fish Farm in the month of August 2014. The fish were fed with commercially available floating feed twice daily@2-2.5\% of their body weight and Vit-E (Selvitdex) was added with supplied feed in the month of October-November for their gonadal maturation. Water quality (water temperature, salinity, dissolved oxygen, $\mathrm{pH}$, alkalinity and ammonia) and fish's health were monitored fortnightly. The salinity in the rearing ponds was maintained between of 15-20 ppt during August-October and 25 ppt during November-February which was the required range for satisfactory gonadal development of mullets.

Hatchery facility development: To develop marine fish hatchery system following facilities were established for broodstock conditioning and subsequent spawning, incubation, larval rearing, and production of live feed. The capacity of various types of holding tanks are shown in Table 1.

Table 1. Tank facilities and capacity used in breeding trials

\begin{tabular}{llccccl}
\hline Stage & Facility & $\begin{array}{c}\text { Stocking } \\
\text { density }\end{array}$ & $\begin{array}{c}\text { Volume } \\
\text { (ton) }\end{array}$ & $\begin{array}{c}\text { Unit } \\
\text { vol. } \\
\text { (ton) }\end{array}$ & $\begin{array}{c}\text { No. } \\
\text { unit }\end{array}$ & Structure \\
\hline Adult & Holding tank & 1 fish/ton & 60 & 30 & 2 & $\begin{array}{l}\text { Square concrete tank, } 6 \mathrm{~m} \times \\
5 \mathrm{~m} \times 1.0 \mathrm{~m} \text { capacity of } 30 \text { tons } \\
\text { with aeration- system }\end{array}$ \\
Broods & $\begin{array}{l}\text { Spawning } \\
\text { tank }\end{array}$ & $\begin{array}{c}1 \text { fish/5 } \\
\text { tons }\end{array}$ & 120 & 30 & 4 & $\begin{array}{l}\text { Square concrete tank, } 6 \mathrm{~m} \times \\
5 \mathrm{~m} \times 1.0 \mathrm{~m} \text { capacity of } 30 \text { tons } \\
\text { with aeration }\end{array}$ \\
Eggs & $\begin{array}{l}\text { Incubation } \\
\text { tank }\end{array}$ & $\begin{array}{c}100 \text { eggs } / \\
\text { liter }\end{array}$ & 8 & 1 & 8 & $\begin{array}{l}\text { Circular/conical shape } 10001 \\
\text { capacity fiber- glass tank }\end{array}$ \\
\hline
\end{tabular}




\begin{tabular}{llcccll}
\hline Stage & Facility & $\begin{array}{c}\text { Stocking } \\
\text { density }\end{array}$ & $\begin{array}{c}\text { Volume } \\
\text { (ton) }\end{array}$ & $\begin{array}{c}\text { Unit } \\
\text { vol. } \\
\text { (ton) }\end{array}$ & $\begin{array}{c}\text { No. } \\
\text { unit }\end{array}$ & Structure \\
\hline Larvae & $\begin{array}{l}\text { Larval rearing } \\
\text { tank }\end{array}$ & $\begin{array}{c}20-50 \\
\text { larvae per } \\
\text { liter }\end{array}$ & 30 & 5 & 6 & $\begin{array}{l}\text { Rectangular concrete tank } \\
(1 \mathrm{~m} \times 1.5 \mathrm{~m} \times 1.5 \mathrm{~m}) \text { of with } \\
\text { aeration }\end{array}$ \\
$\begin{array}{l}\text { Phytoplankt } \\
\text { on }\end{array}$ & $\begin{array}{l}\text { Algal (Nano) } \\
\text { culture tank }\end{array}$ & 8 & 0.5 & 8 & $\begin{array}{l}\text { Flat bottom } 500 \text { liters } \\
\text { fiberglass tank }\end{array}$ \\
Zooplankton & $\begin{array}{l}\text { Rotifer } \\
\text { culture tank }\end{array}$ & 3 & 0.5 & 6 & $\begin{array}{l}\text { Flat bottom } 500 \text { liters } \\
\text { fiberglass tank }\end{array}$ \\
Live feed & $\begin{array}{l}\text { Artemia } \\
\text { culture tank }\end{array}$ & 4 & 0.5 & 8 & $\begin{array}{l}\text { Flat bottom } 500 \text { liters } \\
\text { fiberglass tank }\end{array}$ \\
\hline
\end{tabular}

Hormonal treatment and spawning: Experiments on induced breeding were conducted during winter months of January-February 2015. Fishes were captured by seine net and transported to the holding tanks by plastic drums with anesthesia (phenoxy-ethanol, 2ml/10 1 water). Each tank was provided with continuous water circulation and aeration.

After transportation of broods, they were treated with Furacin (50 ppm for 5 min.), and females and males were separated, followed by sampled of oocytes using Live Ovarian Biopsy (LOB) method. Injections were initiated within 48 hrs after transportation and acclimatization in holding tanks. Interval between injections varied from 24 to $36 \mathrm{hrs}$. Dry carp pituitaries for $1^{\text {st }}$ dose and LRH-A ( $2^{\text {nd }}$ dose) with the combination of Domperidone and Calcium injections were injected in varied doses. HCG was also used in the $1^{\text {st }}$ dose for male in the first trial and for both male and female in the second breeding trial.

Natural spawning in holding tanks with un-injected males was also performed and spawning behavior was closely observed. The eggs were floating and drifting in nature. In case of fecundity study, the spent females were dissected and eggs retaining in the abdomen were counted for estimation of fecundity. Released eggs were continuously monitored by using ocular and stage micrometer to estimate eggs diameter. Fertilized eggs were kept in the spawning tank for incubation after treated with $0.5 \mathrm{ml} / 1$ streptomycin solution and observation continued through microscope until the starting of cell division.

\section{RESULTS AND DISCUSSION}

The biological features of mullets has been well documented (Thompson 1966, Chubb et al. 1981), although relatively less information are available on the reproductive biology of mullets (Render et al. 1995). After four months of rearing in the saline ponds, healthy and diseases free broods transferred to hatchery tanks for breeding trials. Striped mullets are considered as winter 
breeder as well as isochronal spawned fish i.e. they have synchronous gamete development and individual spawned at once (Render et al. 1995, McDonough et al. 2003) and spawning population is not uniform in size distribution. In the first week of January 2015 mullets captured by seine net showed only $70-80 \%$ matured stages of gonadal development through LOB method. In this method, catheter (no.6) gently pushed into the gonad then sucked by mouth for collecting gonad and collected sample observed under microscope to check the development of gonads. Gonado-Somatic Index (GSI) values used to determine sexual differentiation stage in female mullets are given in Table 2. GSI values were positively correlated with oocyte diameter and negatively correlated with oocyte density. GSI of fecund fishes found ranged from 7.92 to 12.38 and final size of vitellogenetic oocytes before hydration $(600 \mu \mathrm{m})$ was corresponding to GSI between 11-12.

Table 2. GSI value of reared striped mullet (Mugil cephalus)

\begin{tabular}{cccccc}
\hline Month & Total wt. & Total L & Gonad wt. & GSI value & Maturity stages \\
\hline Nov, 2014 & $1.63 \mathrm{~kg}$ & $50 \mathrm{~cm}$ & $64 \mathrm{~g}$ & 7.92 & Developing \\
Dec, 2014 & $1.75 \mathrm{~kg}$ & $52 \mathrm{~cm}$ & $85 \mathrm{~g}$ & 8.86 & Yolk granule stage \\
Jan, 2015 & $2.2 \mathrm{~kg}$ & $57 \mathrm{~cm}$ & $181 \mathrm{~g}$ & 12.38 & $\begin{array}{c}\text { Close to mature yolk stage } \\
\text { (80\%) }\end{array}$ \\
\hline
\end{tabular}

The physicochemical parameters of the water in the hatchery tanks were measured daily following standard methods (APHA 1998) and the average values are given in Table 3 . The salinity and other parameters of this study were close to those have been reported by Kuo et al. (1974).

Table 3. Average value of the physicochemical parameters of brood holding (HT)/ breeding (BT)/ spawning tank (ST) during January-February 2015

\begin{tabular}{|c|c|c|c|c|c|c|c|c|c|}
\hline \multirow[t]{2}{*}{$\begin{array}{l}\text { Tank } \\
\text { nos. }\end{array}$} & \multicolumn{2}{|c|}{$\begin{array}{c}\text { Temperature } \\
\left({ }^{\circ} \mathbf{C}\right)\end{array}$} & \multirow{2}{*}{$\begin{array}{c}\begin{array}{c}\text { Salinity } \\
\text { (ppt) }\end{array} \\
9 \text { AM }\end{array}$} & \multicolumn{2}{|c|}{$\mathbf{P}^{\mathbf{H}}$} & \multicolumn{2}{|c|}{ DO (ppm) } & \multirow{2}{*}{$\begin{array}{c}\begin{array}{c}\text { Water } \\
\text { exchange }\end{array} \\
(\%) \text { daily }\end{array}$} & \multirow[t]{2}{*}{$\begin{array}{c}\text { Treatment } \\
\text { with chlorine }\end{array}$} \\
\hline & 9 AM & $6 \mathrm{PM}$ & & 9 AM & $6 \mathrm{PM}$ & 9 AM & 6 PM & & \\
\hline HT-1 & 20.7 & 24.5 & 28.4 & 7.9 & 8.1 & 5.1 & 6.2 & 30 & Initial \\
\hline HT-2 & 20.5 & 23.8 & 28.6 & 7.6 & 8.0 & 5.2 & 6.3 & 30 & do \\
\hline BT-1 & 21.2 & 23.4 & 28.2 & 7.8 & 7.9 & 5.4 & 6.2 & 50 & do \\
\hline BT-2 & 21.7 & 23.8 & 27.7 & 7.8 & 8.0 & 5.3 & 6.1 & 50 & do \\
\hline $\mathrm{ST}-1$ & 21.3 & 25.2 & 28.1 & 7.7 & 7.9 & 5.1 & 5.8 & 50 & Every trial \\
\hline ST-2 & 21.4 & 25.3 & 28.3 & 7.8 & 8.0 & 5.3 & 5.9 & 50 & do \\
\hline ST-3 & 21.6 & 25.8 & 28.5 & 7.9 & 8.0 & 5.5 & 5.7 & 50 & do \\
\hline ST-4 & 21.8 & 25.7 & 28.0 & 7.8 & 7.9 & 5.3 & 6.0 & 50 & do \\
\hline
\end{tabular}


In all the breeding trials attempted, injections were initiated within $48 \mathrm{hrs}$ after transportation and acclimatization. The fishes started pairing just before they spawned, males were observed a little bit active than female in the time of mating. The first release of a small number of eggs stimulated the male to release spermatozoa. Interval between $1^{\text {st }}$ and $2^{\text {nd }}$ dose of injections was maintained at $24 \mathrm{hrs}$ and also in case of $3^{\text {rd }}$ dose. The response of 3 breeding trials are summarized in Tables 4-6.

In order to assess successful spawning performance, two females with two injected males and two un-injected male were kept in holding tanks for overnight. Eight from ten injected females responded with ovulation and spawning (four spawned in tank and rest were stripped) as spawning rate close to $66 \%$. Rest of oocytes from female stripped produced 34\% fertilization. Similar observation was reported by Kuo (1995), having spawning rate of $66 \%$ for $M$. cephalus. From this experimental trials, in most cases fertilization has failed due to poor quality as well as quantity of milts or due to lack of good males, but single spawning produced more than $60 \%$ fertilization rate which was calculated as the total number of fertilized eggs divided by the total sampled number $(n=100)$ of eggs. These results were close to those have been reported by Greeley et al. (1987). Two females out of 10 fishes did not respond to multiple injections and developed Atresia. All the hormones administered separately or combined produced the same results, both positive and negative. Hydration was observed within 6-12 hrs after the injection of effective dose and spawning within 6-8 hrs after beginning of hydration. Initial diameter of oocytes in all the females varied within a range of 550-600 $\mu \mathrm{m}$ (except of one case) showing no significant difference between females with positive and negative response. However, responded females had coalesced oil globule before injections and those which did not respond had partially or not fused oil droplets. Hypophysation produces positive result when the oocytes are at tertiary yolk stage with oil globule coalesced, nucleus migrated and diameter of 650-700 $\mu \mathrm{m}$ (Kuo et al. 1974). The hypophysation results are presented in Table 7 . 
Table 4. $1^{\text {st }}$ Breeding response of Mugil cephalus during $1^{\text {st }}$ week of January 2015

\begin{tabular}{|c|c|c|c|c|c|c|c|c|c|}
\hline \multirow[b]{2}{*}{ Sex } & \multirow[b]{2}{*}{$\begin{array}{l}\text { Body wt } \\
\quad(\mathbf{k g})\end{array}$} & \multirow[b]{2}{*}{$\begin{array}{l}\text { Length } \\
\text { (cm) }\end{array}$} & \multicolumn{3}{|c|}{ Injection dose (unit/fish) } & \multirow[b]{2}{*}{$\begin{array}{c}\text { LP } \\
\text { (hrs) }\end{array}$} & \multirow[b]{2}{*}{$\begin{array}{l}D_{1} \\
(\mu)\end{array}$} & \multirow[b]{2}{*}{$\begin{array}{l}\mathbf{D}_{2} \\
(\mu)\end{array}$} & \multirow{2}{*}{$\begin{array}{c}\text { TSE } \\
\text { (eggs/g } \\
\text { bwt) /MC }\end{array}$} \\
\hline & & & $\begin{array}{l}\text { Priming } \\
\text { (mg/kg) }\end{array}$ & $\begin{array}{l}\text { Resolving } 1 \\
\text { (after } 24 \text { hrs) }\end{array}$ & $\begin{array}{l}\text { Resolving } 2 \\
\text { (after } 24 \text { hrs) }\end{array}$ & & & & \\
\hline Female & 1.05 & 41 & $30 \mathrm{cPG}$ & $\begin{array}{l}\text { LRH-A } 2100 \mu g+0.3 \mathrm{ml} \\
\text { Dom. }+0.5 \mathrm{ml} \mathrm{Ca-} \mathrm{inj.}\end{array}$ & $\begin{array}{l}\text { LRH-A } 250 \mu g+0.3 \mathrm{ml} \\
\text { Dom. }+0.2 \mathrm{ml} \mathrm{Ca-inj.}\end{array}$ & 48 & 565 & 650 & 745 \\
\hline Female & 1.30 & 44 & $40 \mathrm{cPG}$ & $\begin{array}{l}\text { LRH-A } 2150 \mu g+0.3 \mathrm{ml} \\
\text { Dom. }+0.5 \mathrm{ml} \mathrm{Ca-} \mathrm{inj.}\end{array}$ & $\begin{array}{l}\text { LRH-A } 50 \mu g+0.3 \mathrm{ml} \\
\text { Dom.+ } 0.2 \mathrm{ml} \mathrm{Ca-} \mathrm{inj}\end{array}$ & 48 & 580 & 665 & 736 \\
\hline Female & 1.40 & 46 & $45 \mathrm{cPG}$ & $\begin{array}{l}\text { LRH-A } 150 \mu g+0.3 \mathrm{ml} \\
\text { Dom. }+0.5 \mathrm{ml} \mathrm{Ca-} \mathrm{inj.}\end{array}$ & $\begin{array}{l}\text { LRH-A } 250 \mu \mathrm{g}+0.3 \mathrm{ml} \\
\text { Dom. }+0.2 \mathrm{ml} \mathrm{Ca-inj.}\end{array}$ & 48 & 560 & 655 & 821 \\
\hline Male & 0.95 & 38 & - & $5000 \mathrm{IU}$ HCG & - & 36 & & & Less milt \\
\hline Male & 0.92 & 37 & - & $5000 \mathrm{IU}$ HCG & - & 36 & & & Less milt \\
\hline Male & 1.02 & 40 & - & No dose & - & - & & & $\mathrm{N} / \mathrm{R}$ \\
\hline Male & 1.06 & 41 & - & No dose & - & - & & & $\mathrm{N} / \mathrm{R}$ \\
\hline Male & 0.87 & 34 & - & $5000 \mathrm{IU}$ HCG & - & 36 & & & Less milt \\
\hline
\end{tabular}

$\mathrm{LP}=$ Latency period, $\mathrm{D}_{1}=$ Mean ova diameter before priming dose, $\mathrm{D}_{2}=$ Mean ova diameter after spawning, TSE $=$ Total spawned eggs in case of female, $\mathrm{MC}=$ Milt conditions in case of male projected by positive sign, $\mathrm{cPG}=\mathrm{Carp}$ pituitary gland, LRH- $\mathrm{A}_{2}=$ Leutinizing Releaseing Hormone, Dom.= Domperidone (Dopamine), Ca- inj.= Calcium injection, N/R= Not responding 
Table 5. $2^{\text {nd }}$ Breeding response of Mugil cephalus during last week of January 2015

\begin{tabular}{|c|c|c|c|c|c|c|c|c|c|}
\hline \multirow[b]{2}{*}{ Sex } & \multirow[b]{2}{*}{$\begin{array}{l}\text { Body wt } \\
\text { (kg) }\end{array}$} & \multirow[b]{2}{*}{$\begin{array}{l}\text { Length } \\
\text { (cm) }\end{array}$} & \multicolumn{3}{|c|}{ Injection dose (unit/fish) } & \multirow[b]{2}{*}{$\begin{array}{c}\text { LP } \\
\text { (hrs) }\end{array}$} & \multirow[b]{2}{*}{$\begin{array}{l}D_{1} \\
(\mu)\end{array}$} & \multirow[b]{2}{*}{$\begin{array}{l}\mathbf{D}_{2} \\
(\mu)\end{array}$} & \multirow{2}{*}{$\begin{array}{c}\text { TSE } \\
\text { (eggs/g } \\
\text { bwt) / MC }\end{array}$} \\
\hline & & & $\begin{array}{l}\text { Priming } \\
\text { (mg/kg) }\end{array}$ & 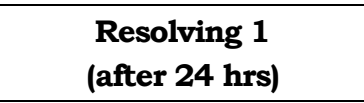 & $\begin{array}{c}\text { Resolving } 2 \\
\text { (after 24 hrs) }\end{array}$ & & & & \\
\hline Female & 1.85 & 53 & $60 \mathrm{cPG}$ & $\begin{array}{l}\text { LRH- } \mathrm{A}_{2} 300 \mu \mathrm{g}+0.3 \mathrm{ml} \\
\text { Dom.+ } 0.5 \mathrm{ml} \mathrm{Ca-} \mathrm{inj.}\end{array}$ & $\begin{array}{l}\text { LRH-A } 250 \mu g+0.3 \mathrm{ml} \\
\text { Dom. }+0.2 \mathrm{ml} \mathrm{Ca-} \mathrm{inj.}\end{array}$ & 48 & 587 & 650 & 892 \\
\hline Female & 1.65 & 49 & $50 \mathrm{cPG}$ & 30000 IU HCG & - & 36 & 563 & 665 & 865 \\
\hline Female & 1.45 & 47 & $45 \mathrm{cPG}$ & 25000 IU HCG & - & - & 570 & - & $\mathrm{N} / \mathrm{R}$ \\
\hline Female & 1.70 & 51 & $55 \mathrm{cPG}$ & $\begin{array}{l}\mathrm{LRH}_{-} \mathrm{A}_{2} 250 \mu \mathrm{g}+0.3 \mathrm{ml} \\
\text { Dom. }+0.5 \mathrm{ml} \mathrm{Ca-inj.}\end{array}$ & $\begin{array}{l}\mathrm{LRH}-\mathrm{A}_{2} 50 \mu \mathrm{g}+0.3 \mathrm{ml} \\
\text { Dom. }+0.2 \mathrm{ml} \mathrm{Ca-} \mathrm{inj.}\end{array}$ & 48 & 570 & 670 & 780 \\
\hline Male & 0.92 & 38 & - & No dose & - & - & & & $\mathrm{N} / \mathrm{R}$ \\
\hline Male & 0.82 & 33 & - & No dose & - & - & & & $\mathrm{N} / \mathrm{R}$ \\
\hline Male & 0.86 & 34 & - & $5000 \mathrm{IU}$ HCG & - & 36 & & & Less milt \\
\hline Male & 0.88 & 36 & - & $5000 \mathrm{IU} \mathrm{HCG}$ & - & 36 & & & Less milt \\
\hline
\end{tabular}


Table 6. $3^{\text {rd }}$ Breeding response of Mugil cephalus in the $1^{\text {st }}$ week of February 2015

\begin{tabular}{|c|c|c|c|c|c|c|c|c|c|}
\hline \multirow[b]{2}{*}{ Sex } & \multirow[b]{2}{*}{$\begin{array}{c}\text { Body wt } \\
(\mathrm{kg})\end{array}$} & \multirow{2}{*}{$\begin{array}{l}\text { Length } \\
\text { (cm) }\end{array}$} & \multicolumn{3}{|c|}{ Injection dose (unit/fish) } & \multirow[b]{2}{*}{$\begin{array}{l}\text { LP } \\
\text { (hrs) }\end{array}$} & \multirow[b]{2}{*}{$\begin{array}{l}D_{1} \\
(\mu)\end{array}$} & \multirow[b]{2}{*}{$\begin{array}{l}\mathbf{D}_{2} \\
(\mu)\end{array}$} & \multirow{2}{*}{$\begin{array}{c}\text { TSE } \\
\text { (eggs/g } \\
\text { bwt) / MC }\end{array}$} \\
\hline & & & $\begin{array}{l}\text { Priming } \\
\text { (mg/kg) }\end{array}$ & $\begin{array}{l}\text { Resolving } 1 \\
\text { (after } 24 \text { hrs) }\end{array}$ & 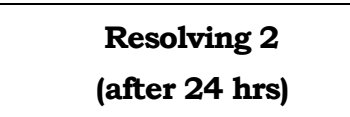 & & & & \\
\hline Female & 1.25 & 42 & $40 \mathrm{cPG}$ & $\begin{array}{l}\text { LRH-A } 100 \mu g+0.3 \mathrm{ml} \\
\text { Dom. }+0.5 \mathrm{ml} \text { Ca- inj. }\end{array}$ & - & 36 & 560 & 645 & 887 \\
\hline Female & 1.48 & 45 & $45 \mathrm{cPG}$ & $\begin{array}{l}\text { LRH-A } 150 \mu \mathrm{g}+0.3 \mathrm{ml} \\
\text { Dom. }+0.5 \mathrm{ml} \text { Ca- inj. }\end{array}$ & $\begin{array}{l}\text { LRH-A } A_{2} 50 \mu g+5 \mathrm{ml} \\
\text { Dom. }+0.2 \mathrm{ml} \mathrm{Ca-} \mathrm{inj.}\end{array}$ & 48 & 575 & 665 & 962 \\
\hline Female & 1.67 & 49 & $50 \mathrm{cPG}$ & 30000 IU HCG & - & 36 & 570 & - & $\mathrm{N} / \mathrm{R}$ \\
\hline Male & 1.13 & 39 & - & No dose & - & 36 & & & $\mathrm{~N} / \mathrm{R}$ \\
\hline Male & 0.96 & 37 & - & $5000 \mathrm{IU}$ HCG & - & 36 & & & $\mathrm{~N} / \mathrm{R}$ \\
\hline Male & 1.06 & 38 & - & $5000 \mathrm{IU}$ HCG & - & 36 & & & $\mathrm{~N} / \mathrm{R}$ \\
\hline Male & 0.85 & 32 & - & No dose & - & 36 & & & $\mathrm{~N} / \mathrm{R}$ \\
\hline Male & 0.87 & 34 & - & $5000 \mathrm{IU}$ HCG & - & 36 & & & $\mathrm{~N} / \mathrm{R}$ \\
\hline
\end{tabular}


Table 7. Hypophyzation of Mugil cephalus in the breeding trials

\begin{tabular}{|c|c|c|c|c|c|c|c|c|}
\hline \multirow{2}{*}{$\begin{array}{c}\text { Weight } \\
\text { of fish } \\
\text { (kg) }\end{array}$} & \multirow{2}{*}{$\begin{array}{c}\text { Length } \\
\text { of fish } \\
\text { (cm) }\end{array}$} & \multirow{2}{*}{$\begin{array}{c}\text { Initial } \\
\text { diameter } \\
\text { of } \\
\text { oocytes } \\
(\mu \mathrm{m})\end{array}$} & \multicolumn{4}{|c|}{ Total dose of hormones per fish } & \multirow{2}{*}{$\begin{array}{l}\text { Number of } \\
\text { injections }\end{array}$} & \multirow{2}{*}{$\begin{array}{c}\text { Responded } \\
\text { signs } \\
(+) /(-)\end{array}$} \\
\hline & & & $\begin{array}{l}\text { PG } \\
\text { (mg) }\end{array}$ & $\begin{array}{c}\text { LRH } \\
(\mu \mathrm{g})\end{array}$ & $\begin{array}{c}\text { Domperidone } \\
(\mu \mathrm{g})\end{array}$ & $\begin{array}{l}\text { HCG } \\
\text { (IU) }\end{array}$ & & \\
\hline 1.05 & 41 & 565 & 30 & 100 & 0.3 & & 3 & + \\
\hline 1.30 & 44 & 580 & 40 & 150 & 0.3 & & 3 & + \\
\hline 1.40 & 46 & 560 & 45 & 150 & 0.3 & & 3 & ++ \\
\hline 1.85 & 53 & 587 & 60 & 300 & 0.3 & & 3 & + \\
\hline 1.65 & 49 & 563 & 50 & - & - & 30000 & 2 & + \\
\hline 1.45 & 47 & 570 & 45 & - & - & 25000 & 2 & $(-)$ \\
\hline 1.70 & 51 & 570 & 55 & 250 & 0.3 & & 3 & + \\
\hline 1.25 & 42 & 560 & 40 & 100 & 0.3 & & 2 & + \\
\hline 1.48 & 45 & 575 & 45 & 150 & 0.3 & & 3 & + \\
\hline 1.67 & 49 & 570 & 50 & - & - & 30000 & 2 & $(-)$ \\
\hline
\end{tabular}

$(++)$ spawned with fertilized eggs, $(+)$ spawned, (-) did not spawned \& atresia checked

In the first trial, only single fertilization took place and the eggs took 44-48 hrs after spawning to hatch out. James et al. (1982) reported that the ideal incubation period of $M$. cephalus was $36-48 \mathrm{hrs}$ at $20-25^{\circ} \mathrm{C}$ of temperatures. All the eggs spawned, fertilized and none had single oil globule. Egg diameter varied within a range of 650-680 $\mu \mathrm{m}$, and oil globules had 250-280 $\mu \mathrm{m}$. Fecundity of those females was determined as 735-900 eggs per gm of body weight. After fertilization cell division started within an hour but the fertilized eggs were settled down before starting further segmentation and finally huge mortality occurred and then the dead eggs were floating throughout the tank. Rapid fluctuation of temperature and poor milt quality as well as quantity of milts might be the main reason of mass egg mortality (Table 8 ).

Table 8. Stages of development Mugil cephalus in breeding trials

\begin{tabular}{clc}
\hline $\begin{array}{c}\text { Age (hrs.) after } \\
\text { fertilization }\end{array}$ & \multicolumn{1}{c}{ Stage of development } & $\begin{array}{c}\text { Temperature of } \\
\text { water }\left({ }^{\circ} \mathbf{C}\right)\end{array}$ \\
\hline 1.00 & Two cells division & 21.5 \\
2.00 & Cell division continued & 22.2 \\
6.00 & Beginning of segmentation, & 24.2 \\
& mortality started & \\
12.00 & High mortality & 25.8 \\
\hline
\end{tabular}

This is the first attempt of induced breeding of Mugil cephalus in a modified marine fish hatchery at Cox's Bazar. This indicates that induced breeding of 
striped mullet is possible and also it could be successfully hypophyzed with hormone injection. Further breeding trials should be conducted using quality broods especially male for fine tuning of hormone induced artificial breeding.

Acknowledgements: The authors gratefully acknowledge the sincere cooperation and regards from Niribili Fish Farm, Cox's Bazar and technical and instrumental supports from Aquaculture for Income \& Nutrition Project (AIN) under USAID, WorldFish, Bangladesh during the breeding trials.

\section{LITERATURE CITED}

APHA (American Public Health Association), 1998. Standard Methods for the Examination of Water and Wastewater, 20th edn. American Public Health Association, Washington DC, USA.

BARMAN, U.K., JANA, S.N., GARG, S.K., BHATNAGAR, A. and DARASU, A.T.R. 2005. Effect of inland water salinity on growth, feed conversion efficiency and intestinal enzyme activity in growing grey mullet, Mugil cephalus (Linn.): field and laboratory studies. Aquaculture International, 13: 241-256.

CHANG, C.W., LIZUKA, Y. and TZENG, W.N. 2004. Migratory environmental history of the grey mullet Mugil cephalus as revealed by otolith $\mathrm{Sr}: \mathrm{Ca}$ ratios. Marine EcologyProgress Series, 269: 277 - 288.

CHANG, C.W., TZENG, W.N. and LEE, Y.C. 2000. Recruitment and hatching dates of grey mullet (Mugil cephalus L.) juveniles in the Tanshui estuary of northwest Taiwan. Zool. Stud., 39: 99-106.

CHUBB, C.F., POTTER, I.C., GRANT, C.J., LENANTON, R.C.J. and WALLACE, J. 1981. Age structure, growth rates and movements of sea mullet, Mugil cephalus L., and yellow eye mullet, Aldrichetta forsteri (Valenciennes) in the Swan Avon river system, Western Australia. Aust. J. Mar. Freshw. Res., 32: 605-628.

CIFRI (Central Inland Fisheries Research Institute), 1961. Annual Report, Central Inland Fisheries Research Institute 1961-62: 55 p.

CURIAN, C.V. 1975. Mullets and mullet fisheries of India. Aquaculture, 5: $114 \mathrm{p}$.

DAS, N.G., HOSSAIN, M.S., BHATTACHARJEE, S. and BARUA, P. 2008. Comparative study for broodstock management of grey mullet (Mugil cephalus L.) in cages and earthen ponds with hormone treatment. Aquaculture Asia: Oct.-Dec.: 30-33.

DE SILVA, S.S. and SILVA, E.I.L. 1979. Biology of young grey mullet, Mugil cephalus L. populations of a coastal lagoon in Sri Lanka. J. Fish Biol., 15: 9-20.

GREELEY, M.S., CALDER, D.R. and WALLACE, R.A. 1987. Oocyte growth and development in the striped mullet, Mugil cephalus, during seasonal ovarian recrudescence: relationship to fecundity and size at mullet maturity. Fish. Bull., 85: 187-200.

JAMES, P.S.B.R., RENAGWASAMY V.S., RAJU A., MOHANRAJ, G. and GANDHI, V. 1982. Induced spawning and larval rearing of grey mullet. Indian J. Fish., 30(2): 185-202.

KUO, C.M. 1995. Manipulation of ovarian development and spawning in grey mullet, Mugil cephalus L. Israel J. Aquacult. Bamidgeh, 47(2): 43-58. 
KUO, C.M., NASH, C.E., and SHEHADEH, Z.H. 1974. A procedural guide to induce spawning in grey mullet (Mugil cephalus L.). Aquaculture, 3: 1-14.

McDONOUGH, C.J., ROUMILLAT, W.A. and WENNER, C.A. 2003. Fecundity and spawning season of striped mullet (Mugil cephalus L.) in South Carolina estuaries. Fish. Bull., 101: 822-834.

RENDER, J.H., THOMPSON, B.A. and ALLEN, R.L. 1995. Reproductive development of striped mullet in Louisiana estuarine waters with notes on the applicability of reproductive assessment methods for isochronal species. Trans. Amer. Fis. Soc., 124(1): 26-36.

SALEH, M. 2008. Capture-based aquaculture of mullets in Egypt. In: Capture-Based Aquaculture, Global Overview: (A. Lovatelli and P.F. Holthus eds.). FAO Fisheries Technical Paper, No. 508. FAO, Rome, 109-126.

THOMPSON, J. M. 1966. The grey mullets. Oecanogr. Mar. Bio. Ann. Rev., 4: 301-335.

YASHOUV, A. and SAMPSONOV, E.B. 1970. Contribution to the knowledge of eggs and early stages of mullet (Mugilidae) along the Israeli coast. Bamidgeh, 22(3): 72-89.

(Manuscript received on 28 August, 2015; revised on 12 September, 2015) 